\title{
Role of berberine in ameliorating Schistosoma mansoni-induced hepatic injury in mice
}

\author{
Mohamed A Dkhil ${ }^{1,2}$
}

\begin{abstract}
Background: Schistosomiasis is caused by helminth parasites of the genus Schistosoma. Berberine chloride (BER), an isoquinoline alkaloid, has been used in vivo for its antiparasitic, antioxidant and hepatoprotective properties. In this study, the protective effect of BER and praziquantel has been compared for the extent of schistosomiasisinduced oxidative stress in hepatic tissue of mice.

Results: S. mansoni was able to induce inflammation and injury to the liver, evidenced (i) by an increase in inflammatory cellular infiltrations, dilated sinusoids and vacuolated hepatocytes, (ii) by decreased levels of alanine and aspartate aminotransferases and increased levels of alkaline phosphatase, $\gamma$-glutamyl transferase in the liver homogenate, (iii) by increased production of nitric oxide and thiobarbituric acid reactive substances, and (iv) by lowered glutathione levels and decreased activities of catalase and superoxide dismutase, respectively. All these infection-induced parameters were significantly altered during BER treatment. In particular, berberine counteracted the S. mansoni-induced loss of glutathione and the activities of catalase and superoxide dismutase.
\end{abstract}

Conclusion: Based on these results, it is concluded that berberine could ameliorate pre-existing liver damage and oxidative stress conditions due to schistosomiasis.

Keywords: Schistosoma mansoni, Berberine, Liver, Mice

\section{Background}

Schistosomiasis is a chronic, parasitic disease caused by blood flukes (trematode worms) of the genus Schistosoma. More than 207 million people are infected worldwide, with an estimated 700 million people at risk in 74 endemic countries (WHO, [1]). Experimental infection of laboratory animals with Schistosoma mansoni has been frequently used as a model for the analysis of the pathological and physiopathological aspects of human infection [2].

There is as yet no vaccine available for Schistosomiasis and the current mainstay of control is chemotherapy with praziquantel (PZQ). In view of concern about the development of tolerance and/or resistance to PZQ, there is a need for research into and development of novel drugs for the prevention and cure of schistosomiasis [3]. Moreover, PZQ is associated with considerable

\footnotetext{
Correspondence: mohameddkhil@yahoo.com

${ }^{1}$ Department of Zoology and Entomology, Faculty of Science, Helwan University, Cairo, Egypt

${ }^{2}$ Department of Zoology, College of Science, King Saud University, P.O. Box: 2455, Riyadh 11451, Saudi Arabia
}

\section{() BioMed Central}

(c) 2014 Dkhil; licensee BioMed Central Ltd. This is an Open Access article distributed under the terms of the Creative Commons Attribution License (http://creativecommons.org/licenses/by/2.0), which permits unrestricted use, distribution, and reproduction in any medium, provided the original work is properly cited. The Creative Commons Public Domain Dedication waiver (http://creativecommons.org/publicdomain/zero/1.0/) applies to the data made available in this article, unless otherwise stated. adverse clinical effects, some occurring within 24 hours [3]. Although the precise mechanism of action of PZQ has not been clarified, it appears to cause severe spasms and paralysis of the worms' muscles. This paralysis is accompanied-and probably caused-by a rapid influx of $\mathrm{Ca}^{2+}$ inside the schistosome $[4,5]$.

Although chemotherapy is still one of the most effective methods for controlling schistosomiasis [6], the value of many of the plant species that have been used throughout the world in traditional medicine for the treatment of both veterinary and human helminthes is increasingly being recognised [7]. Few plants, however, have been screened for activity against adult Schistosoma $s p$., although some medically important species, such as Zingiber officinale, Nigella sativa and Asparagus officinalis, do show an effect against schistosomiasis $[8,9]$.

Berberine is an isoquinoline alkaloid with a long history of medicinal usage. It is a well-known naturally occurring medicine derived from the root and the stem bark of numerous clinically important medicinal plants such as Hydrastis canadensis (goldenseal), Berberis aquifolium (Oregone grape), Berberis aristata (tree turmeric), 
Berberis vulgaris (barbery), and many other plants [10]. Berberine extracts and decoctions have demonstrated significant antimicrobial and antiparasitic activity against a variety of organisms including bacteria, viruses, fungi, protozoans, helminths and Chlamydia [11]. Extensive research within the past decade indicates that berberine is associated with a wide range of pharmacological effects, including antioxidative [12], anti-inflammatory [13], and immunoregulative [14] activities. Several studies have also demonstrated the inhibitory effects of berberine on chemically induced cytotoxicity, lipid peroxidation and oxidative stress in the liver $[15,16]$. In this context, the current study aimed to investigate the role of berberine against schistosomiasis-induced hepatic damage in mice.

\section{Results}

Histological investigation of hepatic tissue sections revealed that $S$. mansoni caused a severe granulomatous inflammatory response in the liver, as indicated by inflammatory cellular infiltration as well as cytoplasmic vacuolation and degeneration of hepatocytes. Granulomas were marked by concentric fibrosis with many fibroblasts encircling the trapped eggs. They were surrounded by a cuff of aggregated lymphocytes, epitheloid cells, eosinophils and collagenous fibres. The presence of numerous granulomas resulted in disorganization of the hepatic strands and lobular structure. In addition, the hepatic sinusoids were dilated and apparently contained more Kupffer cells (Figure 1).

Berberine administration induced a significant reduction in the size of this granulomatous inflammation compared to the livers of infected untreated animals (Figure 1 and Figure 2). While the diameter of the granulomas reached approximately $300 \pm 15.8 \mu \mathrm{m}$ in infected livers, treatment with berberine significantly reduced their diameter to $190 \pm 16.3 \mu \mathrm{m}$. This reduction in granuloma size was similar to that in the PZQ treated group (Group 5) (Figure 1 and Figure 2). In the berberine treated group, meanwhile (group VI), the hepatic lobular architecture appeared to be restored its normal organization and most hepatocytes showed a normal appearance, even in the vicinity of the granulomas. Some sinusoids remained dilated and infiltrated with lymphocytes, however, and some Kupffer cells were still hypertrophied (Figure 1). All these alterations are considered through the histological liver activity index compiled according to Ishak et al. [17], which were categorized from 9-16 for the infected livers in comparison to 1-3 for non-infected controls (Table 1). Moreover, mice treated with PQZ and berberine displayed a highly significant increase in the percentage of egg reduction in the

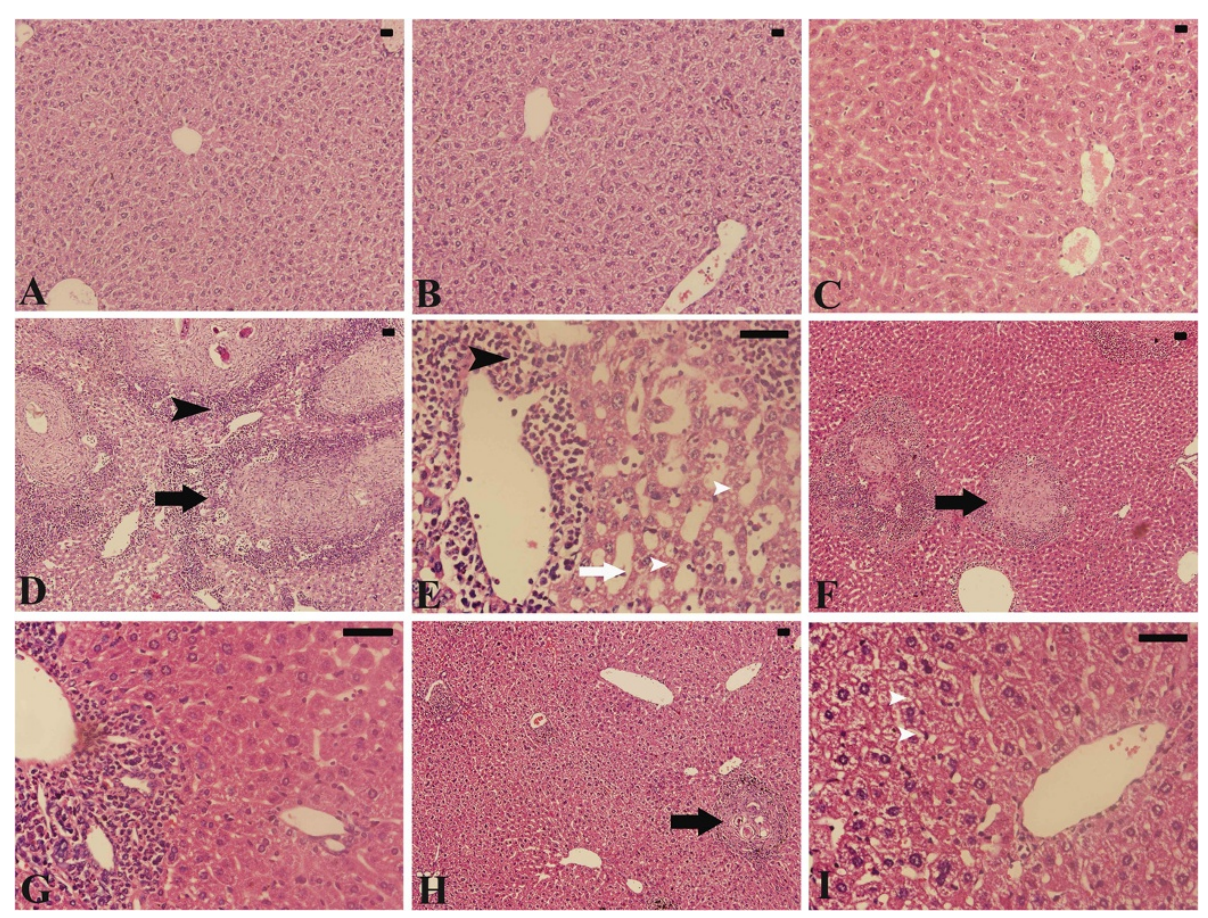

Figure 1 Histological changes in hepatic tissue of non-infected and infected mice with S. mansoni on day 55 p.i. (A) Non-infected liver with normal architecture. (B) Non-infected, PQZ treated mouse liver with normal structure. (C) Non-infected, berberine treated mouse liver with normal structure. (D,E) Infected liver from group 4 with prominent inflammation (black arrow heads) especially around granuloma (black arrow), sinusoidal dilatations (white arrow) and hepatocytic vacuolation. $(\mathbf{F}, \mathbf{G})$ Infected PQZ treated mouse liver from group 5 showing fewer lesions. $(\mathbf{H}, \mathbf{I})$ Infected berberine treated mouse liver from group 6 showing reduced tissue damage. Sections are stained with hematoxylin and eosin. Bar $=50 \mu \mathrm{m}$. 


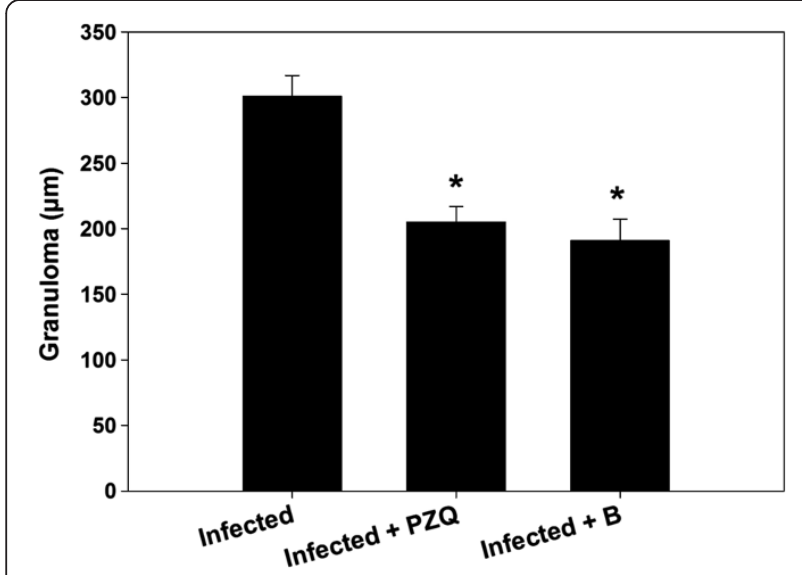

Figure 2 Reduction in granuloma size in the livers of mice infected with $S$. mansoni and treated with berberine. Values are means \pm SD $(n=8)$. * Significant change at $P \leq 0.05$.

liver, estimated as approximately $39 \%$ and $27 \%$ respectively (Figure 3).

Most previous studies have determined the activities of the liver enzymes in the blood serum. In this study, the activities of ALT, AST, ALP and $\gamma$-GT have been measured in the liver homogenates. The activities of ALT and AST in our study were significantly decreased in the liver homogenate of the infected mice (group 3) by approximately $40 \%$ and $50 \%,(P<0.05)$, respectively (Table 2). Liver ALP and $\gamma$ GT in group 3, meanwhile, were significantly elevated by $55 \%$ and $48 \%,(P<0.05)$, respectively. Again, both PQZ and berberine treatments were associated with significant changes in these liver parameters, as can be seen from Table 2 .

S. mansoni also induced a highly significant increase in hepatic NO (Figure 4) and MDA (Figure 5) by approximately 3.5 and 2.3 fold, respectively. Treatment with berberine, however, significantly reduced the $S$. mansoniinduced increase in TBARS and NO (Figure 4 and Figure 5). Finally, some major components involved in the down-regulation of substances formed during oxidative

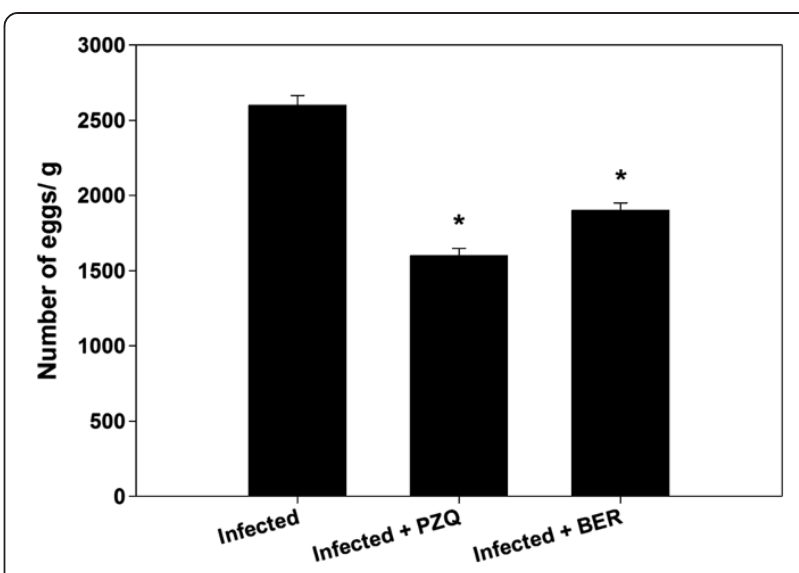

Figure 3 Egg density in the hepatic tissues of mice infected with S. mansoni and treated with PQZ or berberine. Values are means $\pm S D(n=8)$. * Significant change at $P \leq 0.05$.

stress, such as GSH, catalase and SOD, have been determined (Table 3). It was striking that these substances were significantly down-regulated by $S$. mansoni infection but that these effects were largely prevented by berberine treatment (Table 3).

\section{Discussion}

The pharmacologic actions of berberine include metabolic inhibition of certain organisms, inhibition of enterotoxin formation, inhibition of intestinal fluid accumulation and ion secretion, inhibition of smooth muscle contraction, reduction of inflammation and inhibition of platelet aggregation [11]. Praziquantel, meanwhile, works by causing severe spasms and paralysis of the worms' muscles. This paralysis is accompanied-and probably caused-by a rapid influx of $\mathrm{Ca}^{2+}$ inside the schistosome (Doenhoff et al., 2008). Berberine is not considered toxic at doses used in clinical situations, nor has it been shown to be cytotoxic or mutagenic [11].

In this study, the administration of berberine for 10 days was shown to have a pronounced antischistosomal effect. As Cheever [18] observed, hepatic fibrosis in

Table 1 Histopathological changes in hepatic tissue of mice infected with S. mansoni

\begin{tabular}{|c|c|c|c|c|c|c|c|}
\hline \multirow[t]{2}{*}{ Group } & \multirow[b]{2}{*}{$\begin{array}{l}\text { Histological } \\
\text { activity index }\end{array}$} & \multicolumn{6}{|c|}{ Microscopic observation } \\
\hline & & $\begin{array}{l}\text { Necrosis or } \\
\text { apoptosis }\end{array}$ & Hemorrhage & $\begin{array}{l}\text { Disorganized } \\
\text { sinusoids }\end{array}$ & $\begin{array}{l}\text { Infiltration of } \\
\text { lymphocytes }\end{array}$ & $\begin{array}{l}\text { Hyperplasia } \\
\text { of Kupffer cells }\end{array}$ & $\begin{array}{l}\text { Hepatocytic } \\
\text { swelling }\end{array}$ \\
\hline Control & 1 & 0 & 0 & 0 & 0 & 0 & 0 \\
\hline PZQ & 3 & 0 & 0 & + & + & 0 & 0 \\
\hline BER & 2 & + & 0 & 0 & + & 0 & 0 \\
\hline Infected & $14-16$ & +++ & +++ & ++ & +++ & +++ & ++ \\
\hline Infected + PZQ & $9-11$ & ++ & + & + & ++ & ++ & + \\
\hline Infected + BER & $9-12$ & + & + & + & ++ & + & + \\
\hline
\end{tabular}

${ }^{a}$ Modified according to Ishak et al. [17]. Score: 1-3, minimal; 4-8, mild; 9-12, moderate; 13-18, severe. 0: absent; +: mild; ++; moderate; and +++: severe. 
Table 2 Effect of berberine chloride on hepatic ALT, AST, $A L P$ and $Y G T$ in male mice infected with $S$. mansoni

\begin{tabular}{ccccc}
\hline $\begin{array}{c}\text { Experimental } \\
\text { groups }\end{array}$ & $\begin{array}{c}\text { ALT } \\
(\mathbf{U} / \mathbf{g})\end{array}$ & $\begin{array}{c}\text { AST } \\
(\mathbf{U} / \mathbf{g})\end{array}$ & $\begin{array}{c}\text { ALP } \\
(\mathbf{U} / \mathbf{g})\end{array}$ & $\begin{array}{c}\mathbf{\gamma} \text {-GT } \\
\mathbf{( U / g})\end{array}$ \\
\hline Control & $304 \pm 1.8$ & $229 \pm 1.8$ & $16 \pm 1$ & $25 \pm 0.8$ \\
PZQ & $315 \pm 1.7^{\mathrm{a}}$ & $220 \pm 4.5^{\mathrm{a}}$ & $13 \pm 0.3^{\mathrm{a}}$ & $18 \pm 1^{\mathrm{a}}$ \\
BER & $318 \pm 1.4^{\mathrm{a}}$ & $255 \pm 2.3^{\mathrm{a}}$ & $7.4 \pm 0.4^{\mathrm{a}}$ & $15 \pm 0.8^{\mathrm{a}}$ \\
Infected & $218 \pm 3.6^{\mathrm{a}}$ & $125 \pm 1^{\mathrm{a}}$ & $36 \pm 1.2^{\mathrm{a}}$ & $48 \pm 1.6^{\mathrm{a}}$ \\
Infected + PZQ & $263 \pm 1.3^{\mathrm{abc}}$ & $146 \pm 1.9^{\mathrm{abc}}$ & $17 \pm 1^{\mathrm{bc}}$ & $16 \pm 0.5^{\mathrm{ac}}$ \\
Infected + BER & $280 \pm 2.8^{\mathrm{abc}}$ & $182 \pm 2.4^{\mathrm{abc}}$ & $12 \pm 1.6^{\mathrm{abc}}$ & $20 \pm 0.6^{\mathrm{abc}}$
\end{tabular}

Values are means $\pm S D(n=8) .{ }^{a}$ Significant difference as compared with Group I $(p \leq 0.05)$. ${ }^{b}$ Significant difference as compared with corresponding control group $(p \leq 0.05)$. ${ }^{\circ}$ Significant difference as compared with infected group (Group IV) $(p \leq 0.05)$.

infected mice is related to egg numbers, i.e. mice with heavier infection have more total hepatic fibrosis. The study showed the relationship between trapped eggs and encircling fibroblasts, supporting the work of Chesney et al., [19], who described the infiltration of circulating fibroblasts into granulomas and speculated that these cells may be important for attracting lymphocytes as well as forming collagen. Our results show the action of berberine in the form of a significant reduction in egg numbers (Figure 3) together with a significant reduction in the size of granulomas, and a decrease in the number of involutive granulomas compared with the infected control mice. Taken together, these findings suggest a possible antifibrotic role of berberine $[20,21]$. The commonly encountered hepatic alterations in untreated animals were periportal inflammation, sinusoidal infiltration and Kupffer cell activation these features were reduced in

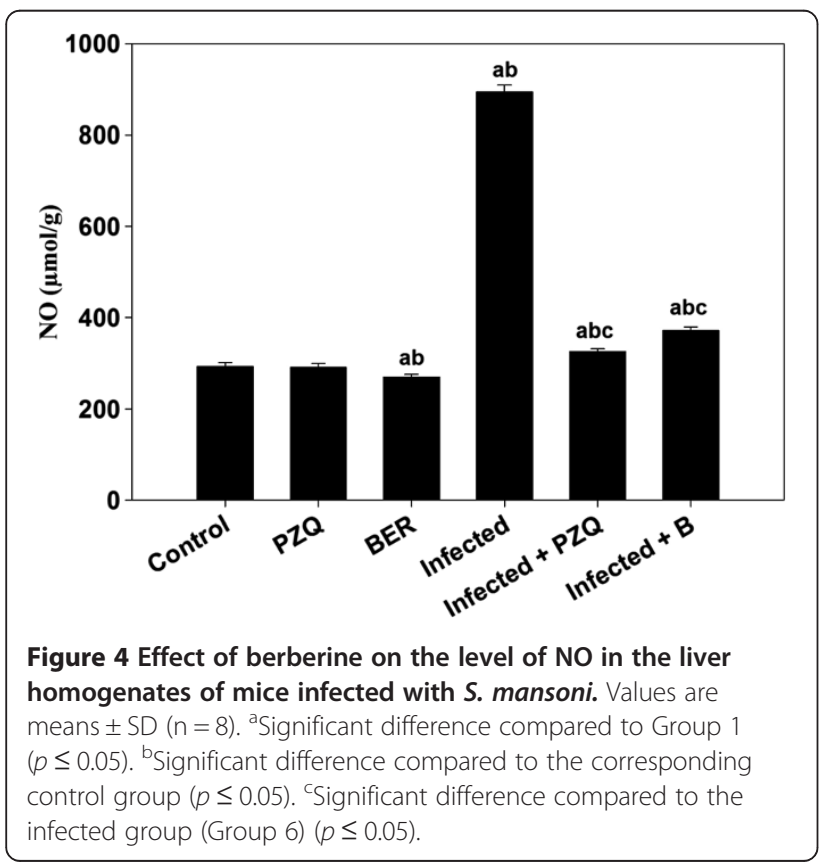

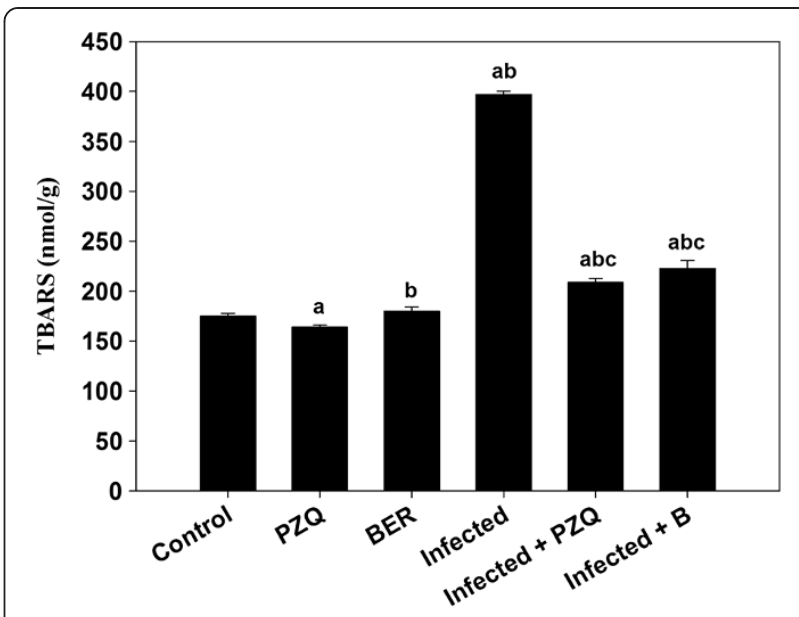

Figure 5 Effect of berberine on the level of malondialdehyde in liver homogenates of mice infected with S. mansoni. Values are means $\pm S D(n=8)$. ${ }^{a}$ Significant difference compared to Group 1 $(p \leq 0.05)$. ${ }^{b}$ Significant difference compared to the corresponding control group ( $p \leq 0.05)$. 'Significant difference compared to the infected group (Group 6) $(p \leq 0.05)$.

animals treated with berberine, further supporting the suggestion of its fibrinolytic effect [20,21].

$S$. mansoni infection is known to induce hepatocellular injury, which in turn, leads to the release of enzymes from the injured hepatic cells into blood circulation [22]. In the present study, the significantly lower levels of AST and ALT in the liver homogenates from the infected groups may be due to the existence of the inflammatory hepatic granuloma reported to be present as a result of egg deposition and the presence of worms and their toxins. Other investigators have found increases in serum transaminases in $S$. mansoni infected animals [23]. The results obtained in this study showed that the anitinflammatory activity of berberine was slightly reflected in an improvement of the status of the bilharzial livers.

Table 3 Effect of berberine on liver glutathione, catalase and superoxide dismutase in male mice infected with S. mansoni

\begin{tabular}{cccc}
\hline $\begin{array}{c}\text { Experimental } \\
\text { groups }\end{array}$ & $\begin{array}{c}\text { GSH } \\
\text { (mmol/g liver) }\end{array}$ & $\begin{array}{c}\text { CAT } \\
\text { (U/g liver) }\end{array}$ & $\begin{array}{c}\text { SOD } \\
\text { (U/g liver) }\end{array}$ \\
\hline Control & $0.8 \pm 0.02$ & $1.3 \pm 0.04$ & $1455 \pm 8.5$ \\
PZQ & $1.1 \pm 0.02^{\mathrm{a}}$ & $1.4 \pm 0.04$ & $1371 \pm 1.4^{\mathrm{a}}$ \\
BER & $1.2 \pm 0.02^{\mathrm{a}}$ & $1.6 \pm 0.01^{\mathrm{a}}$ & $1589 \pm 6.2^{\mathrm{ab}}$ \\
Infected & $0.61 \pm 0.02^{\mathrm{a}}$ & $0.75 \pm 0.02^{\mathrm{a}}$ & $859 \pm 1.3^{\mathrm{a}}$ \\
Infected + PZQ & $0.76 \pm 0.08^{\mathrm{ab}}$ & $1.3 \pm 0.01^{\mathrm{bc}}$ & $902 \pm 2.2^{\mathrm{abc}}$ \\
Infected + BER & $0.67 \pm 0.02^{\mathrm{ab}}$ & $1.2 \pm 0.03^{\mathrm{bc}}$ & $924 \pm 1.7^{\mathrm{abc}}$
\end{tabular}

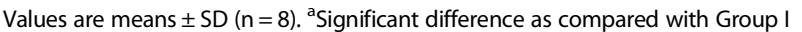
$(p \leq 0.05)$. ${ }^{b}$ Significant difference as compared with corresponding control group ( $p \leq 0.05)$. 'Significant difference as compared with infected group (Group IV) $(p \leq 0.05)$. 
Schistosomiasis is associated with the liberation of free radicals and the disturbance of the cellular antioxidant system. It is known that antioxidant processes play an important role in mediating liver injury in schistosomiasis due to the increased production of reactive oxygen intermediates [24]. Hence, the suppressive effect of berberine on the formulation of granulomas is probably due, in part, to the fact that berberine has an antioxidant effect [25].

GSH is known to play an important role in antioxidant defence, both directly through the scavenging of reactive oxygen species, and indirectly through its function as a cofactor of antioxidant enzymes [26]. It has also been reported that schistosomiasis causes an impairment of the liver GSH content of mice, thus serving to decrease the antioxidant capacity of the liver and leading to the generation of lipid peroxides that may in turn play a central role in the pathology associated with schistosomiasis [27]. In the present study, hepatic GSH decreased significantly (by approximately $31.5 \%$ ) in infected treated mice, compared to the normal control group, which indicates that schistosomiasis causes more liberation of free radicals. Berberine treatment, however, decreased both hepatic lipid peroxidation and GSH depletion strongly suggesting that berberine is an effective antioxidant in this context.

It was observed that the infection caused significant increases in the hepatic TBARS levels. Berberine treatment prevented the increase in TBARS, probably in part by scavenging the very reactive components. Moreover, high rate of oxidative processes, formation of hepatic TBARS due to the peroxidative damage to the liver microsomal membrane lipid and impairment of the antioxidant defense characterize schistosomiasis [28].

Catalase (CAT) has been regarded as a major determinant of hepatic antioxidant status by catalyzing the reduction of hydrogen peroxides and protecting tissue from highly reactive hydroxyl radicals. A decrease in CAT activity could result from inactivation by superoxide radicals and glycation of the enzymes [29]. Moreover, CAT is known to be involved in detoxification of high $\mathrm{H}_{2} \mathrm{O}_{2}$ concentrations, whereas glutathione peroxidase is sensitive to lower concentrations of $\mathrm{H}_{2} \mathrm{O}_{2}$ [29].

Results obtained with berberine are a clear indication of the importance of berberine for the treatment of $S$. mansoni infection, which is comparable to that of praziquantel.

\section{Conclusion}

Collectively, the findings of the present investigation suggest that the way in which BER exerts its beneficial effects on S. mansoni-induced oxidative stress may be attributed to its antioxidant activity, and that this action could find a clinical use in the treatment of hepatic dysfunction in schistosomiasis. Further studies are still necessary, however, in order to elucidate the exact mechanism of this modulatory effect, and to examine its potential therapeutic effects in more detail.

\section{Methods \\ Animals}

Swiss albino mice were bred under specified pathogenfree conditions and fed a standard diet and water ad libitum. The experiments were performed only with male mice at an age of 9-11 weeks; they were approved by state authorities and followed Egyptian rules for animal protection.

\section{Infection of mice}

S. mansoni cercariae were from the Schistosome Biological Supply Center at Theodor Bilharz Research Institute, Imbaba, Giza, Egypt. Mice were exposed to $100 \pm 10$ $S$. mansoni cercariae per mouse by the tail immersion method, modified by Oliver and Stirewalt [30].

\section{Experimental design}

Animals were allocated to six groups of eight mice each. Group one served as a control group and received water (100 $\mu \mathrm{l}$ water/mouse) by oral administration for 10 days. Group two was treated with Praziquantel (PZQ) at $500 \mathrm{mg} / \mathrm{Kg}$ via $70 \%$ glycerine on two successive days. Group three were gavaged with $100 \mu \mathrm{l}$ of $12 \mathrm{mg} / \mathrm{kg}$ berberine chloride (one-third of the 50\% lethal dose) (Sigma, St. Louis, MO, USA) [31] for 10 days. Groups four, five and six were infected with $100 \pm 10 S$. mansoni cercariae. On day 46 p.i. with $S$. mansoni, the animals of groups five and six were given PZQ and Berberine by gavage at the same doses as groups two and three, respectively. On day 55 p.i with S. mansoni, the animals of all groups were killed. Part of the liver was weighed and homogenized immediately to give a $50 \%(\mathrm{w} / \mathrm{v})$ homogenate in an ice-cold medium containing $50 \mathrm{mM}$ Tris $-\mathrm{HCl}$ and $300 \mathrm{mM}$ sucrose, $\mathrm{pH} 7.4$ [32]. The homogenate was centrifuged at $500 \times \mathrm{g}$ for $10 \mathrm{~min}$ at $4^{\circ} \mathrm{C}$. The supernatant $(10 \%)$ was used for the various biochemical determinations.

\section{Egg count in the liver}

The eggs in the liver of infected mice were counted according to Pellegrino et al. [33]. In brief, the number of eggs per gram of liver tissue was determined by weighing a piece of liver $(0.1 \mathrm{~g})$ and divided it into four fragments, each fragment being crushed between a slide and a cover slip. The fragments were then examined by light microscope and the number of eggs counted.

\section{Histology of the liver}

Tissue samples from the livers of mice from each of the groups were immediately fixed after animal dissection in $10 \%$ neutral buffered formalin, dehydrated and processed 
for paraffin sectioning. Sections were then deparaffinised and stained with hematoxylin and eosin. Histological damage was scored according to Jamshidzadeh et al. [34] as follows: 0 : absent; +: mild; ++; moderate; and +++: severe. The liver activity index was estimated using a modified quantitative Ishak scoring system [17]; scores of 1-3 were assigned to cases of minimal liver damage, scores of 4-8 to mild, scores of 9-12 to moderate and scores of 13-18 to severe cases. To assess the size of tissue granuloma, the mean diameter $(\mu \mathrm{m})$ was measured. For each group, 30 granulomas were chosen from different sections and different mice.

\section{Biochemical analysis Aminotransferases}

Colorimetric determination of alanine aminotransferase (ALT) and aspartate aminotransferase (AST) was estimated by measuring the amount of pyruvate and oxaloacetate, respectively, produced by forming 2, 4dinitrophenylhydrazine. The colour of which was measured at $546 \mathrm{~nm}$ according to Reitman and Frankel [35].

\section{Alkaline phosphatase}

Alkaline phosphatase (ALP) was assayed in the liver homogenates using kits provided by Biodiagnostic Company (Giza, Egypt). Also, Total Bilirubin (TB) of serum was assayed according to the method of Schmidt and Eisenburg [36].

\section{$\gamma$-Glutamyl transferase}

$\gamma$-Glutamyl transferase $(\gamma \mathrm{GT})$ was estimated in the liver homogenates according to the method described by Szasz [37]. The substrate L- $\gamma$-glutamyl-4-nitroanilide, in the presence of glycylglycine, is converted by $\gamma \mathrm{GT}$ in the sample to 4-nitroaniline which was measured at $405 \mathrm{~nm}$ in a Jasco-Japan-V530 spectrophotometer.

\section{Glutathione}

Glutathione (GSH) was determined chemically in the liver homogenates using Ellman's reagent [38]. This method is based on the reduction of Ellman's reagent (5,5' dithiobis (2-nitrobenzoic acid) with GSH to produce a yellow compound. The chromogen is directly proportional to the GSH concentration and its absorbance was measured at $405 \mathrm{~nm}$.

\section{Determination of thiobarbituric acid reactive substances}

Thiobarbituric acid reactive substances (TBARS) were assayed through colorimetric tests of the liver homogenates according to the method of Ohkawa et al. [39]. In this method, TBARS was determined by using $1 \mathrm{ml}$ of trichloroacetic acid $10 \%$ and $1 \mathrm{ml}$ of thiobarbituric acid $0.67 \%$ which were then heated together in a boiling water bath for $30 \mathrm{~min}$. TBARS were then determined by the absorbance at $535 \mathrm{~nm}$ and expressed as TBARS formed.

\section{Nitric oxide}

The assay of nitric oxide (NO) in the liver homogenates was done according to the method of Berkels et al., [40]. In an acid medium, and in the presence of nitrite, the formed nitrous acid diazotises sulphanilamide, and this is then coupled with $\mathrm{N}-(1-$ naphthyl) ethylenediamine. The resulting azo dye has a bright reddish-purple colour which was measured at $540 \mathrm{~nm}$.

\section{Statistical analysis}

One-way ANOVA was carried out, and the statistical comparisons among the groups were performed with Duncan's test using a statistical package program (SPSS version 17.0). All $\mathrm{p}$ values are two-tailed and $P<0.05$ was considered as significant for all statistical analysis in this study.

\section{Competing interests}

The authors declare that they have no competing interests.

\section{Acknowledgements}

The author extends his appreciation to the Deanship of Scientific Research at King Saud University for funding the work through the research group project no. RGP-VPP-198.

Received: 24 June 2013 Accepted: 3 October 2013

Published: 1 April 2014

\section{References}

1. World Health Organization: Schistosomiasis, Fact Sheet No 115; 2010 Available at http://www.who.int/mediacentre/factsheets/fs115/en/index. html.

2. Cheever AW, Lenzi JA, Lenzi HL, Andrade ZA: Experimental models of Schistosoma mansoni infection. Mem Inst Oswaldo Cruz 2002, 97:917-940.

3. Wilson RA, Langermans JAM, Van Dam GJ, Vervenne RA, Hall SL, Borges WC, Dillon GP, Thomas AW, Coulson PS: Elimination of Schistosoma mansoni Adult Worms by Rhesus Macaques: Basis for a Therapeutic Vaccine? PLOS Negl Trop Dis 2008, 2:e290.

4. Pinlaor S, Prakobwong S, Hiraku Y, Kaewsamut B, Dechakhamphu S, Boonmars T, Sithithaworn P, Pinlaor P, Ma N, Yongvanit P, Kawanishi P: Oxidative and nitrative stress in Opisthorchis viverrini-infected hamsters: an indirect effect after praziquantel treatment. Am J Trop Med Hyg 2008, 78:564-573

5. Doenhoff MJ, Cioli D, Utzinger J: Praziquantel: mechanisms of action, resistance and new derivatives for schistosomiasis. Curr Opin Infect Dis 2008, 21(6):659-67. http://www.ncbi.nlm.nih.gov/pubmed/18978535.

6. Amer N, Kamel M: Tegumental alteration and immunological changes in murine Schistosomiasis mansoni after treatment with Artemesia extract. J Egypt Med 2002, 26:14-22.

7. Hammond JA, Fielding D, Bishop SC: Prospects for plant anthelmintics in tropical veterinary medicine. Vet Res Commun 1997, 21:213-228.

8. Hoareau L, Dasilva EJ: Medicinal plant: a re-emerging health aid. Electron J Biotechnol 1996, 2:60-65.

9. Tanwer BS, Vijayvergia R: Phytochemical evaluation and quantification of primary metabolites of Alangium salviifolium. Int J Pharm Biosci 2010, 1:1-6.

10. Zuo F, Nakamura N, Akao T, Hattori M: Pharmacokinetics of berberine and its main metabolites in conventional and pseudo germ-free rats determined by liquid chromatography/ion trap mass spectrometry. Drug Metab Dispos 2006, 34:2064-2072. 
11. Birdsall TC, Kelly GS: Berberine: therapeutic potential of an alkaloid found in several medicinal plants. Altern Med Rev 1997, 2:94-103.

12. Rockova L, Majekova M, Kost D, Stefek M: Antiradical and antioxidant activities of alkaloids isolated from Mahonia aquifolium. Structural Aspects Bioorg Med Chem 2004, 12:4709-4715

13. Küpeli E, Koşar M, Yeşilada E, Hüsnü K, Başer C: A comparative study on the anti-inflammatory, antinociceptive and antipyretic effects of isoquinoline alkaloids from the roots of Turkish Berberis species. Life Sci 2002, 72:645-657.

14. Kim TS, Kang BY, Cho D, Kim SH: Induction of interleukin-12 production in mouse macrophages by berberine, a benzodioxoloquinolizine alkaloid, deviates CD4 T cells from a Th2 to a Th1 response. Immunology 2003, 109:407-414.

15. Hwang JM, Wang CJ, Chou FP, Tseng TH, Hsieh YS, Lin WL, Chu CY. Inhibitory effect of berberine on tert-butyl hydroperoxide-induced oxidative damage in rat liver. Arch Toxicol 2002, 76:664-670.

16. Zhang BJ, Xu D, Guo Y, Ping J, Wang H, Chen LB: Protection by and anti-oxidant mechanism of berberine against rat liver fibrosis induced by multiple hepatotoxic factors. Clin Exp Pharmacol Physiol 2008, 35:303-309.

17. Ishak K, Baptista A, Bianchi L, Callea F, Degroote J, Gudat F, Denk H, Desmet V, Korb G, Macsween RNM, Phillips MJ, Portmann BG, Poulsen H, Scheuer PJ: Histological grading and staging of chronic hepatitis. J Hepatol 1995, 22:696-699.

18. Cheever AW: A quantitative post mortem study of Schistosoma mansoni in man. Am J Trop Med Hyg 1968, 17:38-64.

19. Chesney J, Metz C, Stavitsky AB, Bacher M, Bucala R: Regulated production of type I collagen and inflammatory cytokines by peripheral blood fibrocytes. J Immunol 1998, 160:419-425.

20. Eitzman DT, Westrick RJ, Xu Z, Tyson J, Ginsburg D: Hyperlipidemia promotes thrombosis after injury to atherosclerotic vessels in apolipoprotein E-deficient mice. Arteriosd Throm Vas 2000, 20(7):1831-1834. http://www.ncbi.nlm.nih.gov/pubmed/10894825

21. Lane DA, Philippou H, Huntington JA: Directing thrombin. Blood 2005 06:2605-2612

22. Hanna LS, Medhat AM, Abdel-Menem HA: Biochemical changes after subchronic and chronic interaction of Schistosoma mansoni infection in Swiss albino mice with two specific compounds. J Egypt Soc Parasitol 2003, 33:245-260.

23. Attallah AM, Wahba MA, Elsheikha HM, Abbas AT, Abdel Aziz MM, El-Hemaly MA: Outcomes of Schistosoma mansoni infection in outbred albino mice exposed to Larvin contaminant. Parasitol Res 2008, 103:567-576.

24. La Flamme AC, Patton EA, Bauman B, Pearce EJ: IL-4 plays a crucial role in regulating oxidative damage in the liver during schistosomiasis. J Immunol 2001, 166:1903-1911.

25. Zhu X, Guo X, Mao G, Gao Z, Wang H, He Q, Li D: Hepatoprotection of berberine against hydrogen peroxide-induced apoptosis by upregulation of sirtuin 1. Phytother Res 2012, 27:414-421.

26. Franco R, Schoneveld OJ, Pappa A, Panayiotidis MI: The central role of glutathione in the pathophysiology of human diseases. Arch Physiol Biochem 2007, 113:234-258.

27. Cunha GM, Silva VM, Bessa KD, Bitencourt MA, Macêdo UB, Freire-Neto FP, Assis CF, Martins RR, Lemos TM, Freire AC, Almeida MG: Levels of oxidative stress markers: correlation with hepatic function and worm burden patients with schistosomiasis. Acta Parasitol 2012, 57:160-166.

28. El Shenawy NS, Soliman MF, Reyad SI: The effect of antioxidant properties of aqueous garlic extract and Nigella sativa as anti-schistosomiasis agents in mice. Rev Inst Med Trop Sao Paulo 2008, 50:29-36.

29. Rajasekaran S, Sivagnanam K, Subramanian S: Antioxidant effect of Aloe vera gel extract in streptozotocin-induced diabetes in rats. Pharmacol Rep 2005, 57:90-96.

30. Oliver L, Stirewalt MA: An efficient method for exposure of mice to cercariae of Schistosoma mansoni. J Parasitol 1952, 38:19-23.

31. Jahnke GD, Price CJ, Marr MC, Myers CB, George JD: Developmental toxicity evaluation of berberine in rats and mice. Birth Defects Res $B$ Dev Reprod Toxicol 2006, 77:195-206.

32. Tsakiris S, Schulpis KH, Marinou K, Behrakis P: Protective effect of L-cysteine and glutathione on the modulated suckling rat brain $\mathrm{Na}+, \mathrm{K}+,-$ ATPase and $\mathrm{Mg} 2+-$ ATPase activities induced by the in vitro galactosaemia. Pharmacol Res 2004, 49:475-479.
33. Pelligrino J, Oliveria CA, Faria JA, Cunha AC: New approach to the screening of drugs in experimental Schistosoma mansoni in mice. Am J Trop Med Hyg 1962, 11:201-215.

34. Jamshidzadeh A, Baghban M, Azarpira N, Bardbori AM, Niknahad H: Effects of tomato extract on oxidative stress induced toxicity in different organs of rats. Food Chem Toxicol 2008, 46:3612-3615.

35. Reitman S, Frankel S: A colorimetric method for the determination of serum glutamic oxalacetic and glutamic pyruvic transaminases. Am J Clin Pathol 1957, 28:56-63.

36. Schmidt $M$, Eisenburg J: Serum bilirubin determination in newborn infants: a new micromethod for the determination of serum of plasma bilirubin in newborn infants. Fortschr Med 1975, 93:1461-1466.

37. Szaz G: A kinetic photometric method for serum gamma glutamyltranspeptidase. Clin Chem 1969, 15:124-136.

38. Ellman GL: Tissue sulfhydryl groups. Arch Biochem Biophys 1959 82:70-77.

39. Ohkawa $\mathrm{H}$, Ohishi $\mathrm{N}$, Yagi $\mathrm{K}$ : Assay for lipid peroxides in animal tissues by thiobarbituric acid reaction. Anal Biochem 1979, 95:351-358.

40. Berkels R, Purol-Schnabel S, Roesen R: Measurement of nitric oxide by reconversion of nitrate/nitrite to NO. J Humana Press 2004, 279:1-8.

doi:10.1186/0717-6287-47-8

Cite this article as: Dkhil: Role of berberine in ameliorating Schistosoma mansoni-induced hepatic injury in mice. Biological Research 2014 47:8.

\section{Submit your next manuscript to BioMed Central and take full advantage of:}

- Convenient online submission

- Thorough peer review

- No space constraints or color figure charges

- Immediate publication on acceptance

- Inclusion in PubMed, CAS, Scopus and Google Scholar

- Research which is freely available for redistribution

Submit your manuscript at www.biomedcentral.com/submit
C) Biomed Central 